\title{
Effect of agglomeration during coprecipitation: Delayed spinellization of magnesium aluminate hydrate
}

\author{
SOUMEN PAL*, A K BANDYOPADHYAY, S MUKHERJEE ${ }^{\dagger}$, B N SAMADDAR ${ }^{\dagger \dagger}$ and \\ P G PAL \\ Department of Ceramic Technology, Government College of Engineering and Ceramic Technology, \\ Kolkata 700 010, India \\ ${ }^{\dagger}$ School of Material Science and Technology, ${ }^{\dagger \dagger}$ Department of Metallurgical and Material Engineering, \\ Jadavpur University, Kolkata 700 032, India
}

MS received 16 February 2009

\begin{abstract}
Precipitation of magnesium aluminate hydrate with faster addition of ammonia at desired pH causes agglomeration. Agglomerated powder, without any further treatment, on calcination forms intermediate compounds at low temperatures $\left(\leq 900^{\circ} \mathrm{C}\right)$. The intermediate compounds on further heat treatment $\left(\geq 1000^{\circ} \mathrm{C}\right)$ decompose into $\mathrm{MgO}, \mathrm{MgAl}_{2} \mathrm{O}_{4}$ and $\alpha-\mathrm{Al}_{2} \mathrm{O}_{3}$. Effect of agglomeration and absorption of foreign ions such as $\mathrm{Cl}^{-}, \mathrm{SO}_{4}^{2-}$, and $\mathrm{NH}_{4}^{+}$in complex compounds probably cause loss of $\mathrm{Al}^{3+}$ and $\mathrm{Mg}^{2+}$ ions during heat treatment, and stoichiometry changes. Powders prepared by continuous method with better control of process parameters than batch process yields better spinellization.
\end{abstract}

Keywords. Agglomeration; stoichiometry; spinellization; solid solution.

\section{Introduction}

$\mathrm{MgAl}_{2} \mathrm{O}_{4}$ (spinel) has emerged as a potential ceramic material because of its versatile functional properties. Its unit cell is cubic and has a large number of tetrahedral and octahedral sites. Due to its chemical inertness to both acidic and basic slags, it can be used as refractory material in critical applications. Symmetric cubic crystal structure and extraordinary fracture strength $(\sim 500 \mathrm{MPa})$ helps polycrystalline $\mathrm{Mg}-\mathrm{Al}$ spinel $\left(\mathrm{MgAl}_{2} \mathrm{O}_{4}\right)$ bodies to be used in optical engineering applications such as optical window materials, etc. Spinellization reaction is accompanied by volume expansion (Bailey and Russell 1968), and high pure dense spinel bodies of stoichiometric composition is not easy to fabricate from mixture of $\mathrm{Al}_{2} \mathrm{O}_{3}$ and $\mathrm{MgO}$ powders through solid state sintering route (Bakker and Lindsay 1967). Fabrication process usually consists of a two-stage firing process: spinellization of the mixed powders at $\sim 1600^{\circ} \mathrm{C}$, followed by milling, body making and refiring even at higher temperatures.

Different wet chemical routes have been developed in the recent past to prepare phase pure $\mathrm{Mg}-\mathrm{Al}$ spinel at relatively low temperatures. Among different techniques such as coprecipitation (Mukherjee and Samaddar 1966; Bratton 1968; Katanic-Popovic et al 1991; Li et al 2001), sol-gel synthesis of metal alkoxides or inorganic salts

\footnotetext{
*Author for correspondence (soumenpal12@gmail.com)
}

(Lepkova et al 1991; Ye et al 2005), combustion synthesis (Behera et al 2004), spray drying (Delau 1970), spray pyrolysis (Suyama and Kato 1982) and flame spray pyrolysis (Bickmore et al 1996) etc, coprecipitation has advantages over other techniques in terms of cost effectiveness, both chemical and phase purity and obviously bulk production. Many investigators prepared $\mathrm{Mg}_{-}$ Al spinels by coprecipitation and used different combinations of chemically pure inorganic salts of magnesium and aluminium such as chlorides, nitrates, sulphates, etc. Precipitants such as ammonia, oxalic acid, ammonium carbonate or bicarbonate, etc were used. In most cases, the precipitate was washed, filtered, dried and then calcined to prepare stoichiometric $\mathrm{Mg}-\mathrm{Al}$ spinel. Some workers (Singh and Sinha 1997; Ye et al 2005) did not consider washing and filtration of the precipitate in order to avoid cation loss $\left(\mathrm{Mg}^{2+}\right.$ or $\left.\mathrm{Al}^{3+}\right)$, and directly dried and calcined the precipitate to achieve stoichiometric composition. Mukherjee and Samaddar (1966) were the first to prepare $\mathrm{Mg}-\mathrm{Al}$ spinel precursor powder by coprecipitation technique. However, further improvement of the technique in terms of both continuous pilot plant level and batch processes (Samaddar et al 1979) needs further investigation for its product characterization. Previous work (Mukherjee 1968; Bhattacharya and Samaddar 1978) regarding characterization of $\mathrm{Mg}-\mathrm{Al}$ spinel prepared in laboratory level batch size of $100 \mathrm{~g}\left(110^{\circ} \mathrm{C}\right.$ dried) indicates some abnormality in its phase evaluation during calcination. This observation prompted us to study 
the material's behaviour during calcination, which includes some process manipulation to investigate the changes in phase composition and also $\mathrm{MgO}: \mathrm{Al}_{2} \mathrm{O}_{3}$ stoichiometry.

In the present work, coprecipitation techniques (continuous and batch) have been used to prepare magnesium aluminate hydrate (MAH) precursor gel. Products of both the processes were characterized by chemical analysis, particle size distribution, DTA and XRD studies. Quantification of the phases present in calcined powders of both the processes has been done by Rietveld analysis. Some of the results reported earlier have been reviewed for comparison with the present work.

\section{Experimental}

AR grade magnesium chloride and aluminium sulphate were used to prepare a mixed salt solution having $\mathrm{Mg}^{2+}: \mathrm{Al}^{3+}$ ionic ratio $1: 2$. Liquor ammonia (AR grade) was used as precipitant for coprecipitation of $\mathrm{Mg}^{2+}$ and $\mathrm{Al}^{3+}$ as hydrates. Precursor powder prepared by continuous technique was designated as type $\mathrm{A}$, and that of batch process as type B. Temperature during precipitation in both the processes was kept the same.

In the continuous technique (Samaddar et al 1979), $\mathrm{pH}$ was controlled by an automatic $\mathrm{pH}$ control system consisting of motorized ball valve, needle valve, spray gun and flow cell. The gel was precipitated at $\mathrm{pH} 9 \cdot 2 \pm 0.05$, filtered, dried at $110^{\circ} \mathrm{C}$ until constant weight, and then the hard dried powder lumps were agated. In the batch process, a reactor of 100 litres capacity was designed and bulk precipitation was carried out in the $\mathrm{pH}$ range $9 \cdot 0-9 \cdot 5$ by addition of suitable amount of liquor ammonia. Here the precipitation was rapid and vigorous stirring was continued for 10-15 min. The precipitated gel was filtered and the wet cake was stored in sealed acid-alkali resistant polythene containers. The wet cake was dried at $110^{\circ} \mathrm{C}$ until constant weight, and then the hard dried lumps were agated. Due to the hydroscopic nature of the dried mass, fineness of dried powders could not be increased beyond a certain limit in both the processes.

Conventional wet chemical method was used to estimate $\mathrm{MgO}$ and $\mathrm{Al}_{2} \mathrm{O}_{3}$ contents in the dried powder. To measure the solid content, LOI was carried out at $1200^{\circ} \mathrm{C}$, $2 \mathrm{~h}$. Particle size distribution was estimated (ZetaSizer Nano-S, Model-Zen1600, Malvern, USA) by laser beam technique using sodium hexametaphosphate as dispersing agent to evaluate the extent of agglomeration.

\subsection{Thermal treatment of $M A H$}

To investigate the thermochemical changes of the dried powders (types A and B) during heat treatment, DTA was conducted up to $1200^{\circ} \mathrm{C}$ at a heating rate of $10^{\circ} \mathrm{C} / \mathrm{min}$. Agated powders of both the processes were calcined at $600^{\circ}, 900^{\circ}, 1000^{\circ}, 1200^{\circ}$ and $1300^{\circ} \mathrm{C}$ with $2 \mathrm{~h}$ soaking for XRD analysis. Again, to review the effect of agglomeration on extent of spinel formation during calcination, $110^{\circ} \mathrm{C}$ dried hard lumps of the types $\mathrm{A}$ and $\mathrm{B}$ were calcined at $1400^{\circ} \mathrm{C}$ for $2 \mathrm{~h}$. Furthermore, to review whether the precursor hydrates (types $\mathrm{A}$ and $\mathrm{B}$ ) can retain their initial $\mathrm{Mg}^{2+}: \mathrm{Al}^{3+}$ stoichiometry during spray pyrolysis, these were flash calcined at $900^{\circ} \mathrm{C}$ for $2 \mathrm{~h}$. Then the flash calcined powders were further heated at $1300^{\circ} \mathrm{C}$ for $2 \mathrm{~h}$. For XRD studies, all the powders of different temperatures were agated (-200 B S sieve).

\subsection{XRD analysis}

Phase analysis of the calcined powders (types A and B) at each of the temperatures was investigated by XRD (PW 3050/60 Goniometer, PANalytical, The Netherlands). Depending upon the availability, both $\mathrm{CuK}_{\alpha}$ and $\mathrm{CoK}_{\alpha}$ radiations were used. Although due to this, change in ' $2 \theta$ ' value would occur for the peaks, XRD curves of only same type of radiation have been incorporated in any individual figure to maintain parity.

\section{Results and discussion}

Chemical analysis of the $110^{\circ} \mathrm{C}$ dried samples (table 1) indicates that for both the methods, processing parameters have been closely controlled to precipitate $\mathrm{Mg}^{2+}$ and $\mathrm{Al}^{3+}$ in the ionic ratio, $1: 2$. Chemical composition of MAH powder suggests that it must yield stoichiometric spinel if there is no loss of cations $\left(\mathrm{Mg}^{2+}\right.$ or $\left.\mathrm{Al}^{3+}\right)$ during calcination. Abnormal LOI values for both the types A and $\mathrm{B}$ suggest that $\mathrm{MAH}$ powder contained some loosely

Table 1. Chemical analysis of MAH precursors (types A and B).

\begin{tabular}{lcccc}
\hline \multirow{2}{*}{$\begin{array}{l}\text { Sample } \\
\text { identity }\end{array}$} & \multicolumn{2}{c}{$\mathrm{Wt} \%$} & \multirow{2}{*}{\begin{tabular}{c} 
LOI \\
\cline { 2 - 3 }$\left(1200^{\circ} \mathrm{C}, 2 \mathrm{O}\right)$
\end{tabular}} & $\begin{array}{c}\text { Molar ratio } \\
\left(\mathrm{Al}_{2} \mathrm{O}_{3}: \mathrm{MgO}\right)\end{array}$ \\
\hline $\begin{array}{l}\text { Type A } \\
\text { Type B }\end{array}$ & 22.67 & 8.66 & 68.42 & $1.035: 1$ \\
\hline
\end{tabular}

Table 2. Particle size distribution of MAH precursors (types A and B).

\begin{tabular}{lcc}
\hline \multirow{2}{*}{$\begin{array}{l}\text { Particle size } \\
\text { (dia in nm) }\end{array}$} & \multicolumn{2}{c}{ Mean volume (\%) } \\
\cline { 2 - 3 } $531 \cdot 2$ & Type A & Type B \\
$615 \cdot 1$ & $15 \cdot 0$ & - \\
$712 \cdot 4$ & $40 \cdot 0$ & - \\
$825 \cdot 0$ & $35 \cdot 0$ & - \\
$955 \cdot 4$ & $10 \cdot 0$ & - \\
$1484 \cdot 0$ & - & - \\
$1718 \cdot 0$ & - & $51 \cdot 7$ \\
$1990 \cdot 0$ & - & $48 \cdot 3$ \\
\hline
\end{tabular}


bonded water molecules beyond $\mathrm{OH}^{-}$group associated with it. Since the precipitation process is rapid and the parent solution contains $\mathrm{NH}_{4}^{+}, \mathrm{Cl}^{-}$and $\mathrm{SO}_{4}^{2-}$ ions, it is expected that the precipitated gel is considerably agglomerated and may absorb some of these foreign ions to form intermediate compounds. Decomposition of these intermediate compounds to corresponding oxides ( $\mathrm{MgO}$ and $\mathrm{Al}_{2} \mathrm{O}_{3}$ ) or their interaction to form $\mathrm{MgAl}_{2} \mathrm{O}_{4}$ would be accompanied by unusual LOI values. Particle size distribution (table 2) of both types of precursors indicates agglomeration, and the particles are of micron order. $\mathrm{Ob}$ viously, it is expected that further processing of the MAH powders could break the agglomerates to sub-micron or nano level.

\subsection{DTA studies}

MAH precursor is expected to undergo thermochemical changes during heat treatment. TGA, DTGA and DTA of $\mathrm{MAH}$ powder (type B) have recently been reported (Pal et al 2008). For comparison of thermal behaviour of types A and B precursors, their DTA curves have been incorporated in figure 1. Although, both the curves have similar nature of endothermic peaks, the number of peaks in type $\mathrm{A}$ is less and also they are more defined than type B. Both the curves do not exhibit endothermic peaks at $\sim 230^{\circ} \mathrm{C}$ and $\sim 400^{\circ} \mathrm{C}$, and this indicates that they do not contain individual aluminium and magnesium hydroxides (Kim and Saito 2000; Yong and Wang 2002). Endothermic peaks of type A $\left(298^{\circ} \mathrm{C}\right)$ and type $\mathrm{B}\left(326^{\circ} \mathrm{C}\right)$ mostly correspond to hydrate of aluminium, probably consisting of some foreign ions from parent solution.

Furthermore, many high temperature endothermic peaks (up to $1100^{\circ} \mathrm{C}$ ) appear in both the types of precursors. This suggests that $\mathrm{Mg}^{2+}$ along with $\mathrm{Al}^{3+}$ forms intermediate hydrates which do not decompose completely even at $1000^{\circ} \mathrm{C}$. It can be interpreted that this specific behaviour of MAH may be due to the absorption of $\mathrm{Cl}^{-}$, $\mathrm{SO}_{4}^{2-}$ and $\mathrm{NH}_{4}^{+}$ions in its agglomerated structure during its preparation by fast precipitation. Thus it may be su-

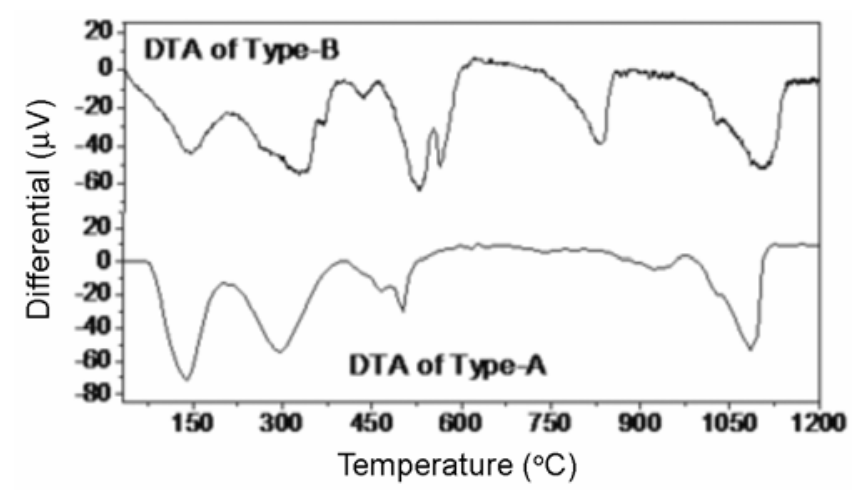

Figure 1. DTA of types A and B MAH precursors $\left(1200^{\circ} \mathrm{C}\right)$. ggested that the formation of aluminium hydrate and double hydrate of magnesium and aluminium as reported (Bratton 1968) took place in the present work, however, the hydrates are complex in nature.

\subsection{Stoichiometry of $M A H$}

During calcination it has been observed that powders of both the processes emit considerable amount of white fumes due to structural decomposition of complex hydrates. Mukherjee (1968) also reported that calcination of MAH under vacuum evolved white vapours containing $\mathrm{Al}^{3+}$ ions, and the stoichiometric composition converted to $\mathrm{MgO}$ enriched spinel. It is expected that there would be loss of $\mathrm{Al}^{3+}$ or $\mathrm{Mg}^{2+}$ ions during calcination. In the present work, the effect of calcination techniques on stoichiometry of $\mathrm{MgAl}_{2} \mathrm{O}_{4}$ has been investigated.

\subsection{XRD interpretation}

XRD curves of low temperature $\left(600^{\circ} \mathrm{C}, 2 \mathrm{~h}\right)$ calcined powders for both the methods in figure 2 indicate the formation of some crystalline intermediate compounds which are different from $\mathrm{Mg}-\mathrm{Al}$ spinel or $\gamma-\mathrm{Al}_{2} \mathrm{O}_{3}$. These compounds retain their identity even at $900^{\circ} \mathrm{C}$ (figure 2). At $1000^{\circ} \mathrm{C}$, the intermediate compounds decompose into $\mathrm{Mg}-\mathrm{Al}$ spinel, periclase $(\mathrm{MgO})$ and some intermediate phases (figure 3). It may be noted that even after $2 \mathrm{~h}$ soaking at $1000^{\circ} \mathrm{C}$, decomposition of the complex compounds is not complete. Formation of $\mathrm{Mg}-\mathrm{Al}$ spinel and

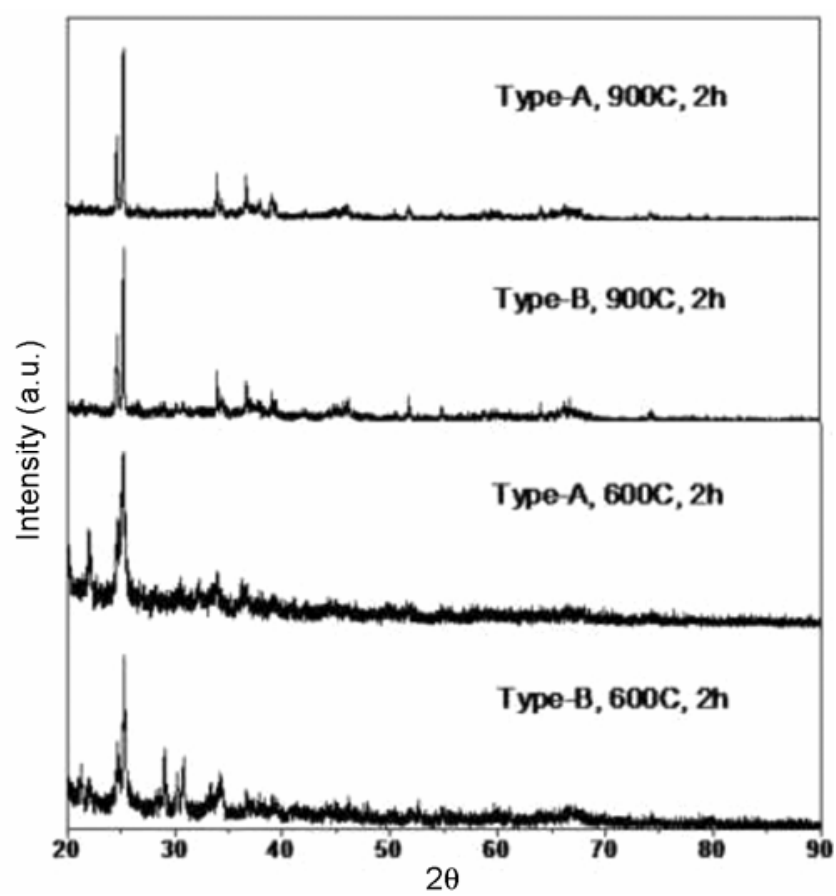

Figure 2. $\mathrm{XRD}$ of types $\mathrm{A}$ and $\mathrm{B} \mathrm{MAH}$ powders at $600^{\circ} \mathrm{C}$ and $900^{\circ} \mathrm{C}\left(\mathrm{CuK}_{\alpha}\right.$ radiation $)$ 
periclase at $1000^{\circ} \mathrm{C}$ indicates double hydrate concept introduced by Bratton (1968). However, thermal stability of the double hydrate even at $900^{\circ} \mathrm{C}$ suggests that the double hydrate contains some foreign ions such as $\mathrm{Cl}^{-}, \mathrm{NH}_{4}^{+}, \mathrm{SO}_{4}^{2-}$ and forms a complex. Peaks of $\gamma-\mathrm{Al}_{2} \mathrm{O}_{3}$ at $1000^{\circ} \mathrm{C}$ are not visible as it forms solid solution with $\mathrm{MgAl}_{2} \mathrm{O}_{4}$. At temperatures $\geq 1200^{\circ} \mathrm{C}, \gamma \rightarrow \alpha$ phase transformation of alumina takes place resulting in exsolution of corundum $\left(\alpha-\mathrm{Al}_{2} \mathrm{O}_{3}\right)$ from $\mathrm{Mg}-\mathrm{Al}$ spinel structure. Then the exsolved alumina reacts with periclase to form secondary spinel. Secondary spinel formation depends on calcination temperature, in general and size of the agglomerates, in particular. It has been observed that even at $1300^{\circ} \mathrm{C}$ (figures 4 and 5), spinellization by interaction of $\mathrm{MgO}$ and $\mathrm{Al}_{2} \mathrm{O}_{3}$ is not complete, since the precipitated $\alpha-\mathrm{Al}_{2} \mathrm{O}_{3}$ from spinel structure can not completely come into contact with $\mathrm{MgO}$ due to large agglomerated size of MAH powder initially taken. Comparison of present work (pilot plant level) with previous laboratory level investigation related to

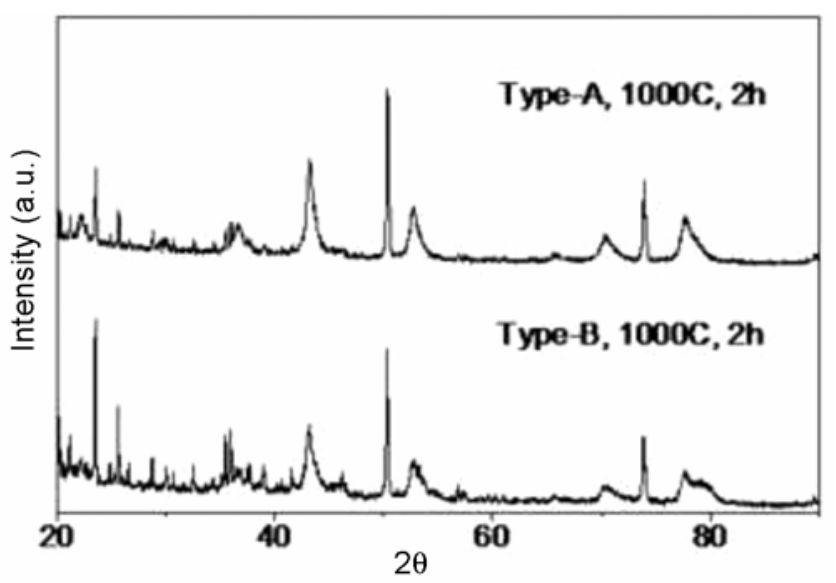

Figure 3. $\mathrm{XRD}$ of types $\mathrm{A}$ and $\mathrm{B} \mathrm{MAH}$ powders at $1000^{\circ} \mathrm{C}$ ( $\mathrm{CoK}_{\alpha}$ radiation).

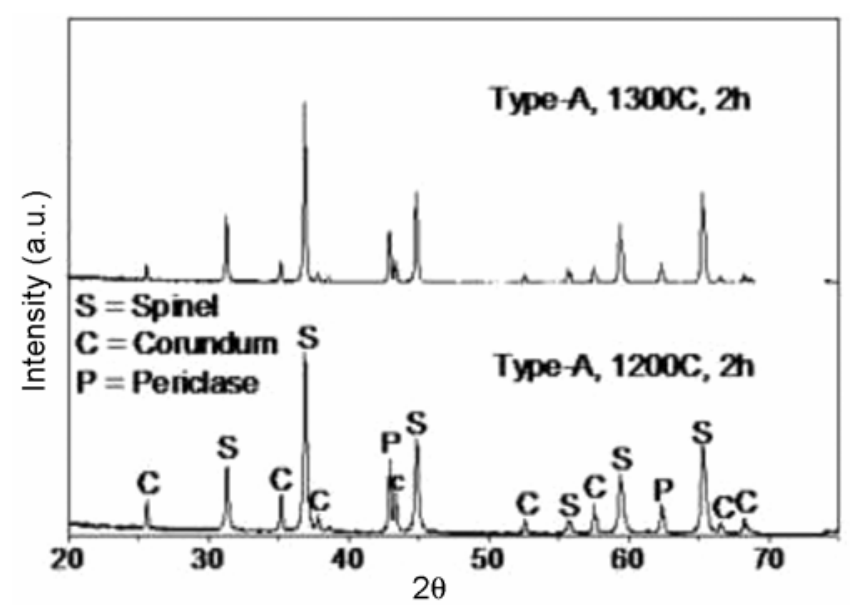

Figure 4. $\mathrm{XRD}$ of type $\mathrm{A} \mathrm{MAH}$ powder at $1200^{\circ}$ and $1300^{\circ} \mathrm{C}$ ( $\mathrm{CuK}_{\alpha}$ radiation). development of various phases during calcination at different temperatures has been incorporated in table 3 . Similar to present investigation, both the researchers (Mukherjee 1968; Bhattacharya and Samaddar 1978) had reported periclase $\left(d_{h k l}=2 \cdot 10 \AA\right)$ at different temperatures along with $\alpha-\mathrm{Al}_{2} \mathrm{O}_{3}$. At low temperatures $\left(\leq 1000^{\circ} \mathrm{C}\right)$, Mukherjee (1968) reported an unidentified phase $\left(d_{h k l}=2.90 \AA\right)$ with maximum intensity and this suggests the formation of intermediate compound that does not decompose at $1000^{\circ} \mathrm{C}$ with $2 \mathrm{~h}$ soaking.

Effect of large agglomerate size is clear when XRD curves of MAH lumps calcined at further higher temperature i.e. $1400^{\circ} \mathrm{C}, 2 \mathrm{~h}$ (figure 6) show poor spinellization. Figure 7 reveals the XRD curves of flash calcined $\left(900^{\circ} \mathrm{C}\right.$, $2 \mathrm{~h})$ powders for both the types at $1300^{\circ} \mathrm{C}, 2 \mathrm{~h}$. Both the curves contain spinel and corundum peaks indicating loss of $\mathrm{Mg}^{2+}$ ions during flash calcination at $900^{\circ} \mathrm{C}$.

Phase quantification of the calcined powders $\left(\geq 1200^{\circ} \mathrm{C}\right)$ was carried out by Rietveld analysis and the results have been incorporated in table 4 . The results of normal calci-

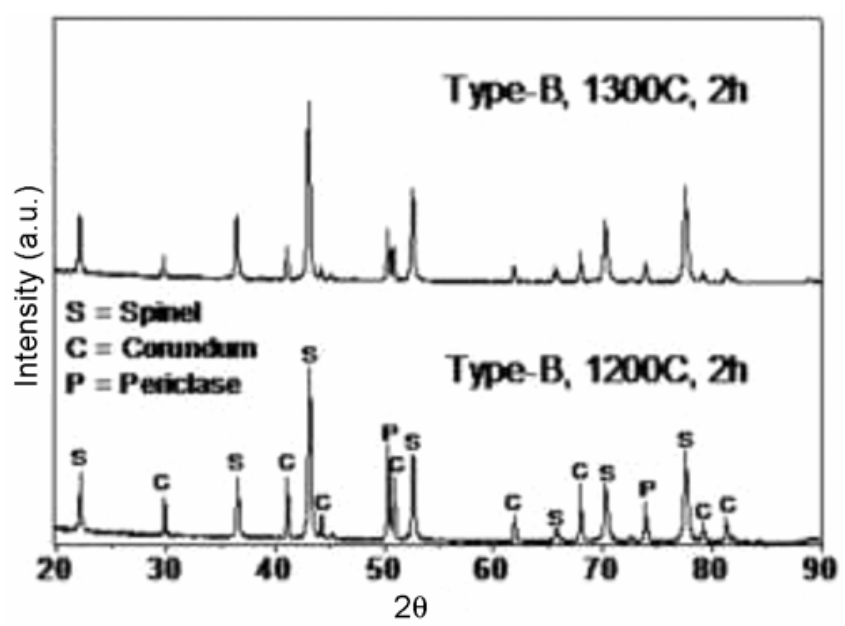

Figure 5. XRD of type B MAH powder at $1200^{\circ}$ and $1300^{\circ} \mathrm{C}$ ( $\mathrm{CoK}_{\alpha}$ radiation)

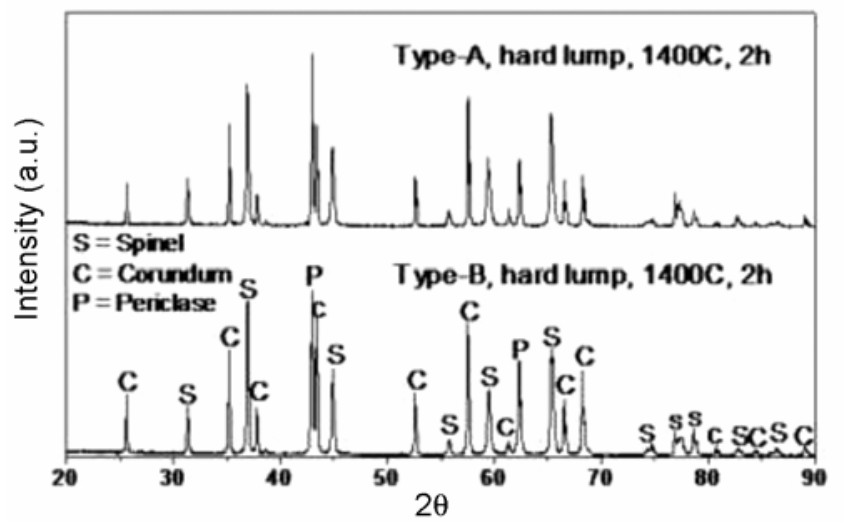

Figure 6. XRD (hard lump) of types A and B MAH powders at $1400^{\circ} \mathrm{C}\left(\mathrm{CuK}_{\alpha}\right.$ radiation $)$ 
Table 3. Comparison of interplanar spacing of some peaks of calcined MAH powder (present and previous works).

\begin{tabular}{|c|c|c|c|c|c|c|c|c|c|c|c|c|c|c|c|}
\hline \multicolumn{6}{|c|}{ Mukherjee (1968) } & \multicolumn{4}{|c|}{ Bhattacharya et al (1978)* } & \multicolumn{6}{|c|}{ Present work (type B) } \\
\hline \multicolumn{2}{|c|}{$800^{\circ} \mathrm{C}$} & \multicolumn{2}{|c|}{$1000^{\circ} \mathrm{C}$} & \multicolumn{2}{|c|}{$1350^{\circ} \mathrm{C}$} & \multicolumn{2}{|c|}{$1100^{\circ} \mathrm{C}$} & \multicolumn{2}{|c|}{$1200^{\circ} \mathrm{C}$} & \multicolumn{2}{|c|}{$900^{\circ} \mathrm{C}$} & \multicolumn{2}{|c|}{$1000^{\circ} \mathrm{C}$} & \multicolumn{2}{|c|}{$1200^{\circ} \mathrm{C}$} \\
\hline$d_{h k l}$ & $I / I_{0}$ & $d_{h k l}$ & $I / I_{0}$ & $d_{h k l}$ & $I / I_{0}$ & $d_{h k l}$ & $I / I_{0}$ & $d_{h k l}$ & $I / I_{0}$ & $d_{h k l}$ & $I / I_{0}$ & $d_{h k l}$ & $I / I_{0}$ & $d_{h k l}$ & $I / I_{0}$ \\
\hline & & & & $4 \cdot 67$ & 10 & $4 \cdot 607$ & VW & $4 \cdot 605$ & W & & & $\begin{array}{l}5.445 \\
4.398 \\
4.04\end{array}$ & $\begin{array}{l}32 \\
94 \\
40\end{array}$ & $4 \cdot 653$ & 33 \\
\hline $3 \cdot 78$ & 20 & $3 \cdot 78$ & 10 & & & & & & & $\begin{array}{l}3.604 \\
3.523\end{array}$ & $\begin{array}{r}53 \\
100\end{array}$ & & & & \\
\hline $2 \cdot 90$ & 100 & $2 \cdot 90$ & 100 & $2 \cdot 601$ & 10 & $2 \cdot 806$ & $\mathrm{~W}$ & $2 \cdot 821$ & M & $2 \cdot 634$ & 32 & $2 \cdot 901$ & 32 & $2 \cdot 851$ & 35 \\
\hline $\begin{array}{l}2 \cdot 56 \\
2 \cdot 43\end{array}$ & $\begin{array}{l}30 \\
30\end{array}$ & $\begin{array}{l}2 \cdot 57 \\
2.43\end{array}$ & $\begin{array}{l}20 \\
80\end{array}$ & 2.43 & 100 & $2 \cdot 400$ & $\mathrm{M}$ & $\begin{array}{l}2 \cdot 562 \\
2 \cdot 398\end{array}$ & $\begin{array}{l}\text { VW } \\
\text { VS }\end{array}$ & $2 \cdot 445$ & 31 & 2.432 & 45 & $\begin{array}{l}2 \cdot 546 \\
2 \cdot 432\end{array}$ & $\begin{array}{r}22 \\
100\end{array}$ \\
\hline $2 \cdot 10$ & 30 & $2 \cdot 10$ & 30 & $2 \cdot 102$ & 50 & $2 \cdot 092$ & VW & $2 \cdot 105$ & S & & & $2 \cdot 107$ & 100 & $\begin{array}{l}2 \cdot 104 \\
2 \cdot 082\end{array}$ & $\begin{array}{l}28 \\
24\end{array}$ \\
\hline 1.81 & 20 & 1.81 & 10 & & & 1.984 & $\mathrm{M}$ & 1.990 & $\mathrm{~S}$ & $2 \cdot 017$ & 11 & $2 \cdot 023$ & 19 & $2 \cdot 017$ & 50 \\
\hline 1.78 & 20 & 1.77 & 10 & 1.757 & 20 & & & & & 1.762 & 19 & & & 1.738 & 11 \\
\hline 1.70 & 30 & 1.70 & 20 & 1.65 & 10 & 1.633 & W & 1.631 & $\mathrm{~W}$ & & & & & $\begin{array}{l}1.648 \\
1.600\end{array}$ & $\begin{array}{r}6 \\
18\end{array}$ \\
\hline 1.55 & 10 & 1.55 & 40 & $1 \cdot 553$ & 50 & & & 1.535 & S & & & & & $\begin{array}{l}1.554 \\
1.489\end{array}$ & $\begin{array}{l}30 \\
11\end{array}$ \\
\hline 1.43 & 20 & 1.43 & 40 & $1 \cdot 365$ & 10 & $1 \cdot 399$ & $\mathrm{M}$ & 1.412 & VS & 1.410 & 18 & 1.429 & 17 & $\begin{array}{l}1.427 \\
1.403 \\
1.373\end{array}$ & $\begin{array}{r}52 \\
7 \\
11\end{array}$ \\
\hline
\end{tabular}

*W, weak; VW, very weak; M, medium; S, strong; VS, very strong.

Table 4. Phase composition of MAH precursors (types A and B) calcined at different temperatures under various process conditions.

\begin{tabular}{|c|c|c|c|c|c|c|c|c|c|c|c|}
\hline \multirow[b]{2}{*}{ Sample details } & \multirow[b]{2}{*}{$\begin{array}{l}\text { Temp. } \\
(2 \mathrm{~h})\end{array}$} & \multicolumn{5}{|c|}{ Phase composition of type A } & \multicolumn{5}{|c|}{ Phase composition of type B } \\
\hline & & $\mathrm{MgAl}_{2} \mathrm{O}_{4}$ & $\alpha-\mathrm{Al}_{2} \mathrm{O}_{3}$ & $\mathrm{MgO}$ & $\begin{array}{l}\mathrm{MgO}: \\
\mathrm{Al}_{2} \mathrm{O}_{3}\end{array}$ & $\begin{array}{c}\text { \%Wt loss } \\
\left(\mathrm{Al}_{2} \mathrm{O}_{3} /\right. \\
\mathrm{MgO})\end{array}$ & $\mathrm{MgAl}_{2} \mathrm{O}_{4}$ & $\alpha-\mathrm{Al}_{2} \mathrm{O}_{3}$ & $\mathrm{MgO}$ & $\begin{array}{l}\mathrm{MgO}: \\
\mathrm{Al}_{2} \mathrm{O}_{3}\end{array}$ & $\begin{array}{c}\% \mathrm{Wt} \text { loss } \\
\mathrm{Al}_{2} \mathrm{O}_{3} / \\
\mathrm{MgO}\end{array}$ \\
\hline \multirow[t]{2}{*}{$\begin{array}{l}\text { Powder (normal } \\
\text { calcination) }\end{array}$} & $\begin{array}{l}1200^{\circ} \mathrm{C} \\
\text { (agated) }\end{array}$ & $72 \cdot 7$ & $15 \cdot 5$ & $11 \cdot 8$ & $1 \cdot 212: 1$ & $\begin{array}{c}17 \cdot 51 \\
\left(\mathrm{Al}_{2} \mathrm{O}_{3}\right)\end{array}$ & $72 \cdot 5$ & $17 \cdot 0$ & $10 \cdot 5$ & $1 \cdot 139: 1$ & $\begin{array}{c}12 \cdot 18 \\
\left(\mathrm{Al}_{2} \mathrm{O}_{3}\right)\end{array}$ \\
\hline & $\begin{array}{l}1300^{\circ} \mathrm{C} \\
\text { (agated) }\end{array}$ & $77 \cdot 0$ & $13 \cdot 8$ & $9 \cdot 2$ & $1 \cdot 137: 1$ & $\begin{array}{c}12 \cdot 06 \\
\left(\mathrm{Al}_{2} \mathrm{O}_{3}\right)\end{array}$ & $77 \cdot 4$ & $13 \cdot 0$ & $9 \cdot 6$ & $1 \cdot 165: 1$ & $\begin{array}{c}14 \cdot 16 \\
\left(\mathrm{Al}_{2} \mathrm{O}_{3}\right)\end{array}$ \\
\hline $\begin{array}{l}\text { Lump (normal } \\
\text { calcination) }\end{array}$ & $\begin{array}{l}1400^{\circ} \mathrm{C} \\
\text { (agated) }\end{array}$ & $44 \cdot 1$ & $31 \cdot 0$ & $24 \cdot 9$ & $1 \cdot 511: 1$ & $\begin{array}{c}33 \cdot 82 \\
\left(\mathrm{Al}_{2} \mathrm{O}_{3}\right)\end{array}$ & $39 \cdot 0$ & $40 \cdot 1$ & $20 \cdot 9$ & $1 \cdot 188: 1$ & $\begin{array}{c}15 \cdot 81 \\
\left(\mathrm{Al}_{2} \mathrm{O}_{3}\right)\end{array}$ \\
\hline $\begin{array}{l}\text { Powder (flash } \\
\text { calcination } \\
\text { at } 900^{\circ} \mathrm{C}, 2 \mathrm{~h} \text { ) }\end{array}$ & $\begin{array}{l}1300^{\circ} \mathrm{C} \\
\text { (agated) }\end{array}$ & $88 \cdot 9$ & $11 \cdot 1$ & - & $0 \cdot 851: 1$ & $\begin{array}{c}14 \cdot 84 \\
(\mathrm{MgO})\end{array}$ & $86 \cdot 5$ & $13 \cdot 2$ & $0 \cdot 3$ & $0 \cdot 835: 1$ & $\begin{array}{c}16 \cdot 52 \\
(\mathrm{MgO})\end{array}$ \\
\hline
\end{tabular}

nation powders indicate increased spinellization for both the processes with higher calcination temperatures. But for coarser agglomerates (lumps), spinellization is delayed even at $1400^{\circ} \mathrm{C}$. From this, it can be interpreted that primary spinel formation by the decomposition of intermediate double hydrate is not dependent on the size of agglomerates. However, in secondary spinel formation, $\mathrm{MgO}$ produced has to come into contact with alumina and therefore, spinellization in case of coarser agglomerates gets restricted. From phase compositions of $\mathrm{MgAl}_{2} \mathrm{O}_{4}$, $\mathrm{MgO}$ and $\mathrm{Al}_{2} \mathrm{O}_{3}$ by Rietveld analysis, mass balance was done to estimate the molar ratio of $\mathrm{MgO}: \mathrm{Al}_{2} \mathrm{O}_{3}$ in calcined powders. Furthermore, with this molar ratio, percent wt loss of either $\mathrm{Al}_{2} \mathrm{O}_{3}$ or $\mathrm{MgO}$ was calculated (table 4). In case of normal heat treatment route, $\mathrm{Al}_{2} \mathrm{O}_{3}$ loss has been observed in both the types of powders, and it 


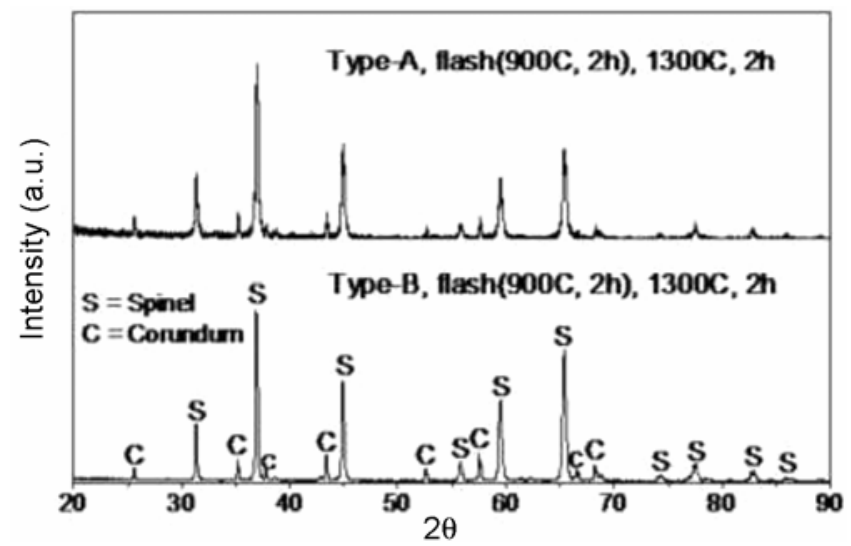

Figure 7. XRD of flash calcined $\left(900^{\circ} \mathrm{C}, 2 \mathrm{~h}\right)$ types $\mathrm{A}$ and $\mathrm{B}$ $\mathrm{MAH}$ powders at $1300^{\circ} \mathrm{C}\left(\mathrm{CuK}_{\alpha}\right.$ radiation $)$.

increases with the size of the agglomerates. Again, $\mathrm{MgO}$ loss occurred for flash calcined powders resulting in alumina enriched spinel. Further in depth investigation may be necessary to establish the reasons of either $\mathrm{Al}_{2} \mathrm{O}_{3}$ or $\mathrm{MgO}$ loss during different modes of calcination of $\mathrm{MAH}$ precursors.

\section{Conclusions}

From the present work, following conclusions can be drawn:

(I) Precursors formed by both the processes (types A and

B) convert to some intermediate compounds which are thermally stable even at $900^{\circ} \mathrm{C}$. Thus spinel formation gets restricted at low temperatures.

(II) Although major decomposition of the intermediate compounds starts at $1000^{\circ} \mathrm{C}$, it is not complete at this temperature. Decomposition is accompanied by the formation of $\mathrm{MgO}$ and spinel phases. The alumina present at $1000^{\circ} \mathrm{C}$ exists as solid solution with spinel.

(III) At $\geq 1200^{\circ} \mathrm{C}$, decomposition of the complexes is complete forming $\mathrm{MgO}$ and spinel. Alumina which was present as solid solution in spinel structure separates out as $\alpha-\mathrm{Al}_{2} \mathrm{O}_{3}$, and it interacts with $\mathrm{MgO}$ to form secondary spinel. However, effect of agglomeration is detrimental for this $\mathrm{MgO}$ and $\mathrm{Al}_{2} \mathrm{O}_{3}$ interaction, and the formation of spinel gets restricted.
(IV) Mode of heat treatment has effect on stoichiometry of spinel. Normal heating causes loss of $\mathrm{Al}^{3+}$ ions forming magnesia enriched spinel, whereas flash calcination effects loss of $\mathrm{Mg}^{2+}$ ions resulting in alumina enriched spinel.

\section{Acknowledgement}

The authors appreciate the Refractory Technology Group, Tata Steel, Jamshedpur, for their cooperation in conducting the X-ray tests of the samples.

\section{References}

Bailey J T and Russell R J R 1968 Ceram. Bull. 471025

Bakker W T and Lindsay J G 1967 Am. Ceram. Soc. Bull. 46 649

Behera S K, Barpanda P, Pratihar S K and Bhattacharya S 2004 Mater. Lett. 581451

Bhattacharya Hemanta and Samaddar B N 1978 J. Am. Ceram. Soc. 61279

Bickmore C R, Waldner K F, Treadwell D R and Laine R M 1996 J. Am. Ceram. Soc. 791419

Bratton R J 1968 Am. Ceram. Soc. Bull. 48759

Delau J G M 1970 Am. Ceram. Soc. Bull. 49572

Katanic-Popovic J, Miljevic N and Zec S 1991 Ceram. Int. 17 49

Kim W and Saito F 2000 Powder Technol. 113109

Lepkova D, Bartarjav A, Samuneva B, Ivanova Y and Georgieva L 1991 J. Mater. Sci. 264861

Li J-G, Ikegami T, Lee J-H, Mori T and Yajima Y $2001 \mathrm{~J}$. Eur. Ceram. Soc. 2139

Mukherjee S G 1968 Spinel formation from co-precipitated magnesium with hydrous aluminium oxide, $\mathrm{PhD}$ Thesis, Banaras Hindu University, Varanasi

Mukherjee S G and Samaddar B N 1966 Trans. Ind. Ceram. Soc. 2533

Pal Soumen, Bandyopadhyay A K and Pal P G 2008 Trans. Ind. Ceram. Soc. 67203

Samaddar B N, Paul P G and Bhattacharya Hemanta 1979 Trans. Ind. Ceram. Soc. 38151

Singh V K and Sinha R K 1997 Mater. Lett. 31281

Suyama Y and Kato A 1982 Ceram. Int. 817

Ye Guotian, Oprea George and Troczynski Tom 2005 J. Am. Ceram. Soc. 883241

Yong C C and Wang J 2002 J. Am. Ceram. Soc. 841225 